\title{
Gold-Silver Electroless Plating on Laser Powder-Bed Fusion Additively Printed AlSi10Mg Parts
}

\author{
Alexandra Inberg ${ }^{1}$, Dana Ashkenazi ${ }^{2, *}{ }^{\mathbb{C}}$, Giora Kimmel ${ }^{3}$, Yosi Shacham-Diamand ${ }^{1,4}(\mathbb{C}$ and \\ Adin Stern 3,5 \\ 1 School of Electrical Engineering, Tel Aviv University, Ramat Aviv 6997801, Israel; \\ inberg@tauex.tau.ac.il (A.I.); yosish@eng.tau.ac.il (Y.S.-D.) \\ 2 School of Mechanical Engineering, Tel Aviv University, Ramat Aviv 6997801, Israel \\ 3 Department of Materials Engineering, Ben-Gurion University of the Negev, Beer Sheva 8410501, Israel; \\ gyorakimmel@gmail.com (G.K.); aandls@gmail.com (A.S.) \\ 4 Department of Materials Science and Engineering, Tel Aviv University, Ramat Aviv 6997801, Israel \\ 5 Department of Mechanical Engineering, Afeka Academic College of Engineering, Tel Aviv 6910717, Israel \\ * Correspondence: dana@eng.tau.ac.il; Tel.: +972-3-6405579
}

Received: 5 April 2020; Accepted: 24 April 2020; Published: 26 April 2020

\begin{abstract}
The current research presents a novel methodology for surface finishing of printed AlSi10Mg parts by electroless deposited gold-silver (electrum) alloys. The parts were printed by additive manufacturing laser powder-bed fusion (AM-LPBF). The electrum was chosen due to its appearance and good electrical and thermal properties and was deposited on disk-shaped specimens at 80 and $90^{\circ} \mathrm{C}$. The coating quality and appearance were studied by different methods for various deposition times and film thicknesses. The results indicate that $\mathrm{Au}-\mathrm{Ag}$ coatings of AM-LPBF AlSi10Mg yield satisfactory results. The XRD analysis revealed that the coatings were composed of $\mathrm{Au}-\mathrm{Ag}$ crystalline phases and beneath them, a quasi-amorphous or mixed quasi-amorphous and nanocrystalline Ni-P interlayer. The mechanism of electrum formation was studied based on the XPS analysis results as a function of the temperature and concentration. At $80^{\circ} \mathrm{C}$, the Ag was dominant at the beginning of the deposition process, while at $90^{\circ} \mathrm{C}$ the Au was first detected on the interface. This result was explained by the electrochemical properties of alloying metals and the binding energies required to form metal-Ni and $\mathrm{Au}-\mathrm{Ag}$ bonding. The results indicate that the electrum coatings are satisfactory, and the developed surface finishing process could be used for many applications.
\end{abstract}

Keywords: additive manufacturing; AlSi10Mg substrate; electroless plating; gold-silver coating; $\mathrm{NiP}$ interlayer; laser powder-bed fusion

\section{Introduction}

\subsection{Additive Manufacturing}

Additive manufacturing (AM) is a group of advanced technologies fabricating three-dimensional custom-built and sophisticated components by addition instead of removal of material. The parts are built layer by layer with fewer tools and less scrap production than the conventional manufacturing technologies, while saving time and expenses [1,2]. In fact, AM enables the formation of complex geometries that up until recently were considered impossible by conventional technologies [3-5]. Thanks to innovative designs, topology-optimized assemblies can be created without significant extra cost. AM technologies allow optimization of lightweight products and are currently used in various industries such as the biomedical, automotive, aerospace, and others [6-10].

Laser powder bed fusion (LPBF) technology, also known as selective laser melting (SLM), is one of the most significant AM technologies used for production of metal components. In AM-LPBF the 
objects are additively built directly from CAD design data, layer upon layer along the $z$-axis (the build-direction), perpendicular to the build-platform ( $x y$-plane) [3,6-9].

Aluminum alloys are successfully processed with LPBF, mainly with the Al-Si casting alloys $[3,8]$. AM-LPBF AlSi10Mg alloy is applied in different applications, including aviation and aerospace, automotive, microelectronics, and other industries, due to its low density, good mechanical properties, high thermal conductivity and excellent corrosion resistance [11]. The corrosion resistance of printed AlSi10Mg alloy produced by AM-LPBF depends on the post-printing heat-treatments and surface conditions, including its roughness [12-14].

The surface roughness of the printed AlSi10Mg part is directly linked to the bulk melt pool track stability and thus directly linked to LPBF process parameters (e.g., laser beam properties). It is also affected by the orientation and position of the component on the build-platform as well as the presence of external defects, such as incompletely fused feedstock powder that locally stick to the external molten area of the object [3-5,15]. For some applications, additional post-LPBF processes are often needed to improve corrosion resistance, electrical and thermal properties and/or due to esthetic considerations. Such stages may include post heat treatment $[13,14]$, machine finishing, and coatings [11,12,16-21].

\subsection{Electroless Plating of Gold-Silver Alloy}

Electroless deposition (ELD) is a controlled method applied at relatively low temperatures $\left(<100{ }^{\circ} \mathrm{C}\right)$ for producing thin metal (Me) and metal alloy coating. This is a process in which a catalytic substrate is immersed into an aqueous solution containing reducing agents and metal ions. The electroless plating is based on chemical reduction reactions and does not require an external potential. The electrons required for the metal reduction are supplied by the simultaneous oxidation of a reducing agent. The process is self-initiating and auto-catalytic [22].

It is quite a simple and inexpensive method, enabling production of rather uniform deposits, especially in the case of rough surfaces and deep holes, without an external current source (as electroplating) or vacuum technology equipment (rich and complicated) [23-25]. ELD is a very promising technology among the diverse thin film fabrication methods, since it can be applied to both conductive and non-conductive surfaces [26-28]. There are various formulations of silver and gold ELD available in the literature, which are often used for commercial applications [29]. While several articles have been published on electrochemical deposition of $\mathrm{Au}-\mathrm{Ag}$ alloy films [30-32] and different nano-structures [33-37], no formulations of ELD for Au-Ag alloy coatings presents in the literature [38].

Even though AlSi10Mg has advanced corrosion resistance many environments, the natural oxide layer that covers aluminum surfaces is very thin, and therefore is far from providing total protection. Hence, aluminum alloys, such as AlSi10Mg, often tend to suffer from local corrosion attacks, such as pitting corrosion. Therefore, it is common to add a nickel-phosphorus (NiP) coating to aluminum alloys in order to protect the surface from wear and to improve its hardness and corrosion resistance [28,29].

There are industrial electroless processes of silver and gold, nevertheless, the related information is limited due to commercial confidentiality. Moreover, such commercial processes usually contain hazardous materials such as cyanide chemical compounds [21].

Various metal coatings can be used in order to improve the electrical, optical, and mechanical properties of AlSi10Mg 3D-printed parts manufactured by LPBF. Such coating may also be applied according to esthetic considerations. The gold and silver coating of AM-LPBF AlSi10Mg parts can efficiently protect the surface against hostile environments and processes [26].

The surface of ancient gold and silver coins and jewelry tends to be rough due to long term corrosion processes in aggressive environments [39]. The prestige appearance of a gold-silver coating can be used for various applications, such as 3D-printed replicas of ancient monuments, status artifacts, and coins for museum exhibitions. The objective of this research is to study the electroless gold-silver binary system surface finishing process for AM-LPBF AlSi10Mg parts. For that purpose, an electroless $\mathrm{Au}-\mathrm{Ag}$ coating was developed and the surface was characterized by various techniques. 


\subsection{Electrum Alloy}

Electrum is an alloy of gold and silver (Figure 1a) that has been used since the first millennium BCE. For example, the first metal coins used in ancient times (around 630-620 BCE) were made of electrum [39]. The metallic radius of gold and silver metals are almost essentially equal, with values of $0.14420 \mathrm{~nm}$ and $0.14447 \mathrm{~nm}$, respectively [40]; and both gold and silver have face-centered cubic (FCC) unit cells, with a lattice parameter of $4.078 \AA$ and $4.086 \AA$ (Figure 1b), respectively [38,41,42]. Therefore, the Au-Ag system (equilibrium phase diagram, Figure 1) consists of a continuous series of solid solution alloys [38,43]. Electrum typically contains 60-80 wt \% of Au and 20-40 wt \% of $\mathrm{Ag}$ [35]. Yet ancient electrum objects often contain higher concentrations of Ag [44,45]. For example, an electrum bar decorated with granules from the Nablus Hoard, dated to the fourth century BCE was composed of 35.5-77.4 wt \% Ag and 21.6-64.5 wt \% Au [39].
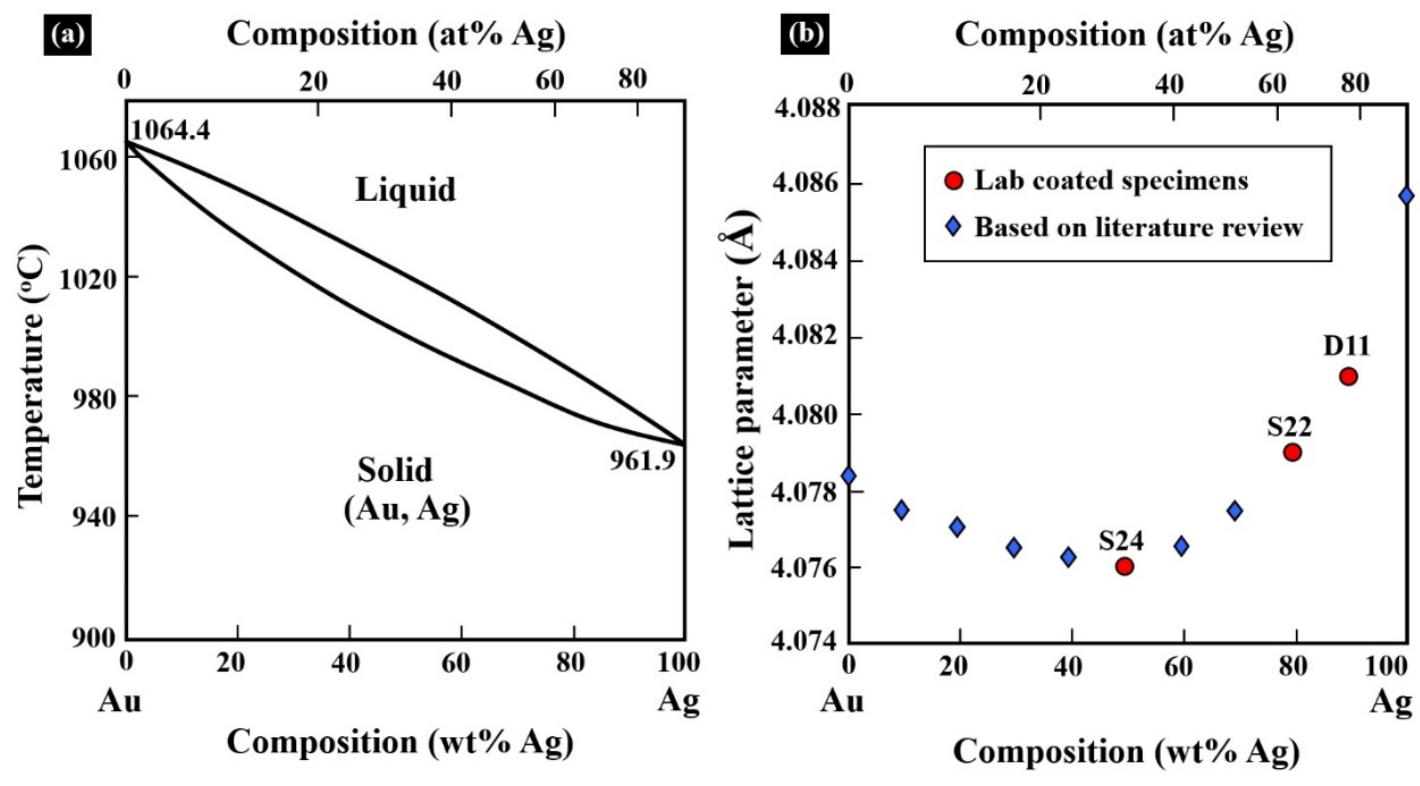

Figure 1. Gold-silver system: (a) Equilibrium phase diagram of the gold-silver system [38]; and (b) lattice parameter of gold, silver and electrum based on data received from literature review [38,41,42] and the present electrum coated printed specimens D11, S22, and S24.

The Au-Ag system is a significant noble bimetallic alloy, both historically and from an advanced nanotechnology perspective, as it is used in catalysis and has great potential for nanomedical applications [31,46].

The aim of this research, as a part of an ongoing project, is to study the electroless surface finishing process for AM-LPBF AlSi10Mg parts using a simple, low cost and environmentally friendly laboratory electroless electrum coating.

\section{Materials and Experimental Methods}

In this research, an $\mathrm{Au}-\mathrm{Ag}$ alloy was electroless deposited on AM-LPBF AlSi10Mg disk-shaped specimens. The specimens had been designed to simulate the geometry and surface appearance of ancient metal coins.

\subsection{Specimens}

The disk-shaped specimens (Figure 2) were 3D-printed by gas-atomized virgin AlSi10Mg alloy powder (composed of aluminum alloy with $10 \mathrm{wt} \% \mathrm{Si}$ and up to $0.45 \mathrm{wt} \% \mathrm{Mg},<0.35 \mathrm{wt} \% \mathrm{Mn}$, $<0.10$ wt $\% \mathrm{Cu},<0.55$ wt \% Fe) [21]. The powder, with particle diameter of between 20-63 $\mu \mathrm{m}$, was supplied by EOS (electro-optical systems) GmbH Company, Krailling, Germany. The specimens 
were LPBF printed in an inert atmosphere of argon using an EOSINT M 280 instrument (Aniwaa, Central Singapore, Singapore), equipped with $400 \mathrm{~W}$ laser; and the build-platform dimensions were $250 \times 250 \times 300 \mathrm{~mm}^{3}$. The spot diameter of the laser beam was $\sim 100 \mu \mathrm{m}$ and its scanning velocity was $\sim 1 \mathrm{~m} \cdot \mathrm{sec}^{-1}$. The build-platform temperature was about $35^{\circ} \mathrm{C}$ through the manufacturing process.

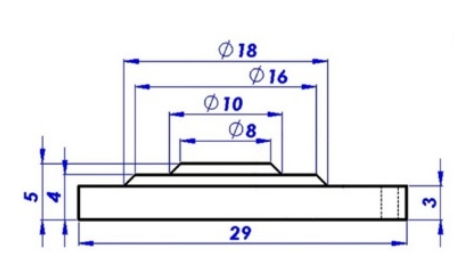

(a)

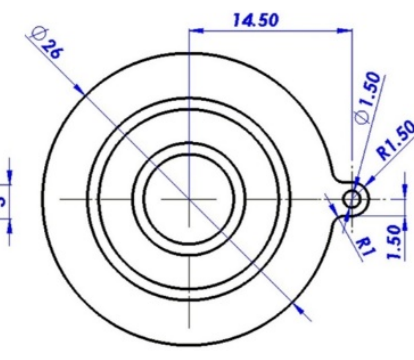

(b)

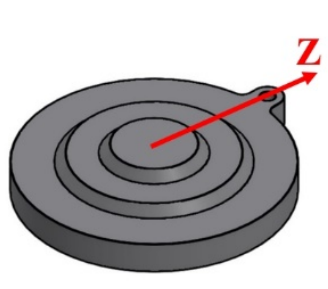

(c)

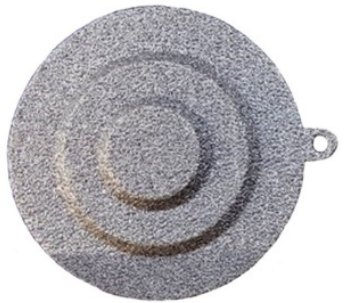

(d)

Figure 2. Disk-shaped specimen: (a,b) solids CAD model: front and top views, respectively; (c) CAD isometric model, where $\mathrm{Z}$ is the print direction (red arrow), and (d) 3D AM-LPBF 3D-printed AlSi10Mg specimen.

The AM-LPBF AlSi10Mg disk-shaped specimens $(26 \mathrm{~mm}$ in diameter) were built in the vertical $\mathrm{Z}$ direction (Figure 2c), with the circular surface perpendicular to the build-platform. The printed specimens were T5 heat-treated at $300{ }^{\circ} \mathrm{C}$ for $2 \mathrm{~h}$ and then cooled in still air. Since the T6 heat treatment changes the microstructure attained through the AM-LPBF process a T5 heat treatment was applied as recommended [21]. The specimens contain an obverse side with two steps, simulating the roughness of ancient coins [21,39] (each step height is $1 \mathrm{~mm}$ ), and a planar surface on the reverse (back) side.

\subsection{Electroless Coating of Au-Ag on Top of 3D Printed AlSi10Mg}

An electroless $\mathrm{Au}-\mathrm{Ag}$ plating process was developed in the present study (Figure 3). Prior to the deposition process, the surfaces of all AlSi10Mg specimens were cleaned and etched in a $12 \mathrm{~g} / \mathrm{l} \mathrm{SDS}$ (sodium dodecyl sulphate) solution at room temperature for $10 \mathrm{~min}$ in an ultrasonic bath (Figure $3 \mathrm{~b}$ ). The quality of the coating is intensely dependent on both the pretreatment of the printed substrates and the cleaning process. The cleaning process reduced the weight of the AlSi10Mg specimens by $0.001 \mathrm{~g}$. Next, a sensitization process was applied in a $\mathrm{SnCl}_{2} / \mathrm{HCl}\left(70 \mathrm{~g} / \mathrm{l}\right.$ of $\mathrm{SnCl}_{2}$ and $\left.40 \mathrm{~mL} / \mathrm{lof} \mathrm{HCl}\right)$ solution at room temperature for $2 \mathrm{~min}$ (Figure 3c). Surface palladium activation was performed in a Pd-citrate solution $\left(0.1 \mathrm{~g} / \mathrm{l}\right.$ of $\mathrm{PdCl}_{2}, 7.35 \mathrm{~g} / \mathrm{l}$ of citric acid, $2.8 \mathrm{~g} / \mathrm{l}$ of $\mathrm{NaOH}$ and $\left.2.4 \mathrm{~g} / \mathrm{l} \mathrm{of} \mathrm{HCl}\right)$ at room temperature for $1 \mathrm{~min}$ (Figure 3d). This step is applied in order to create metal catalytic seeds that serve as nucleation sites. A NiP interlayer was electroless deposited (Figure 3e, Table 1) on the specimens to improve adhesion of the alloy to the substrate. Only then was the electroless electrum $(\mathrm{Au}-\mathrm{Ag})$ plating finally performed (Figure $3 \mathrm{f}$, Table 2$)$ at two temperatures $\left(80\right.$ and $\left.90^{\circ} \mathrm{C}\right)$ and time intervals between 1.5 and $9 \mathrm{~min}$. The 3D-printed specimens were washed both after each step and at the end of the $\mathrm{Au}-\mathrm{Ag}$ deposition process in DI water. Following the electrum deposition, the $\mathrm{Au}-\mathrm{Ag}$ coated specimens (Figure 4, specimens D10-D12, S19, S21-S27) were heated in an air oven at $100{ }^{\circ} \mathrm{C}$ for 30-60 min. 


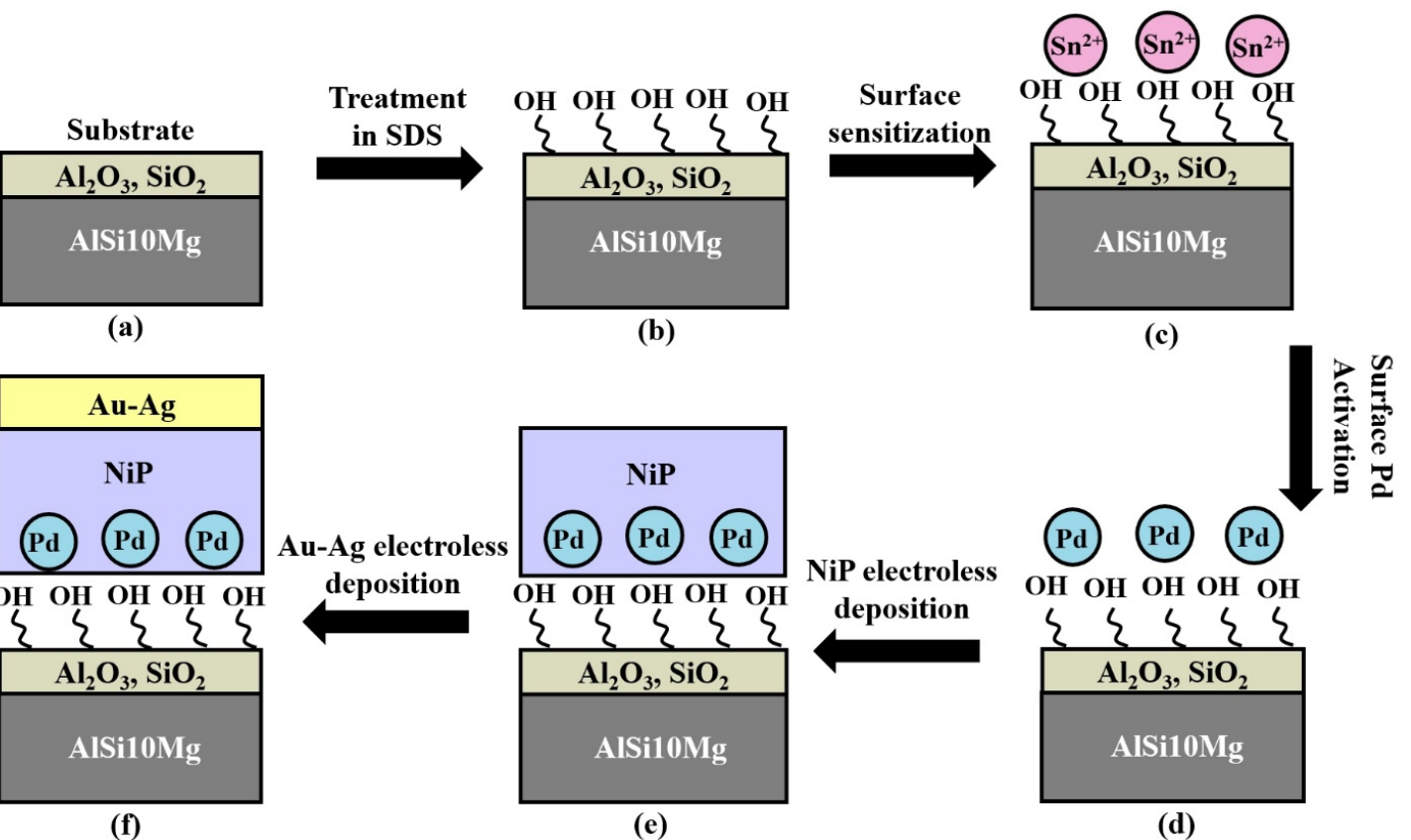

Figure 3. Schematic process flow of the electroless Au-Ag plating for AM AlSi10Mg finishing: (a) the as printed AlSi10Mg substrate (Mg oxide is not presented since AlSi10Mg alloy contains less than $0.5 \mathrm{wt} \% \mathrm{Mg}$ ), (b) treatment in SDS, (c) sensitization surface treatment, (d) surface palladium activation, (e) deposition of $\mathrm{NiP}$ interlayer, and (f) electroless $\mathrm{Au}-\mathrm{Ag}$ plating.

Table 1. Composition of the NiP solution ( $\mathrm{pH} 4-6$ ), which was used for the deposition of NiP interlayer. The NiP deposition was performed at temperature of $95^{\circ} \mathrm{C}$ for $2 \mathrm{~h}$.

\begin{tabular}{|c|c|}
\hline Component & Concentration $(\mathrm{g} / \mathrm{l})$ \\
\hline $\mathrm{NiSO}_{4} \cdot 6 \mathrm{H}_{2} \mathrm{O}$ & 30 \\
\hline $\mathrm{NaCH}_{3} \mathrm{COO}$ & 5 \\
\hline 3-Na-citrate & 12.6 \\
\hline $\mathrm{NaH}_{2} \mathrm{PO}_{2}$ & 10 \\
\hline
\end{tabular}

Table 2. Developed electrum bath composition ( $\mathrm{KOH}$ to $\mathrm{pH}=12)$. $\mathrm{Au}-\mathrm{Ag}$ deposition (1:2 molar ratio of solution) was performed at temperatures of 80 and $90{ }^{\circ} \mathrm{C}$, and time intervals between 1.5 and $9 \mathrm{~min}$.

\begin{tabular}{cc}
\hline Component & Concentration \\
\hline $\mathrm{KAu}(\mathrm{CN})_{2}$ & $7 \mathrm{mM}$ \\
\hline $\mathrm{KAg}(\mathrm{CN})_{2}$ & $3.5 \mathrm{mM}$ \\
\hline 3-Na-citrate $\left(3 \mathrm{Na}_{3} \mathrm{C}_{6} \mathrm{H}_{5} \mathrm{O}_{7}\right)$ & $170 \mathrm{mM}$ \\
\hline Hydrazine hydrate & $15 \mathrm{mM}$ \\
\hline PEG 1500 & $0.5 \mathrm{~g} / 1$ \\
\hline Sodium saccharin & $0.5 \mathrm{~g} / 1$
\end{tabular}




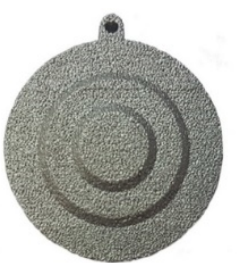

As printed

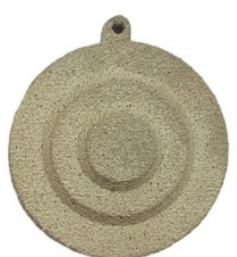

S19

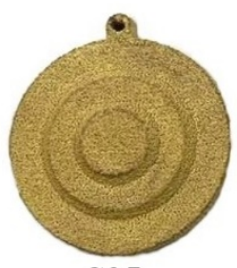

S25

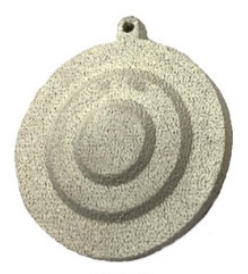

D10

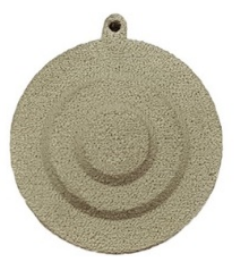

S21

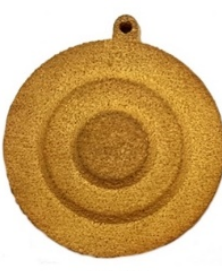

S26

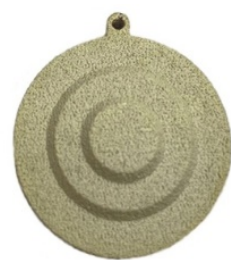

D11

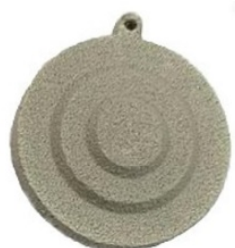

S23

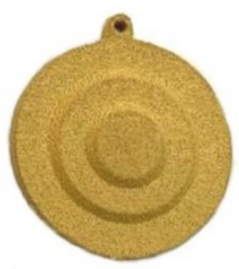

S24

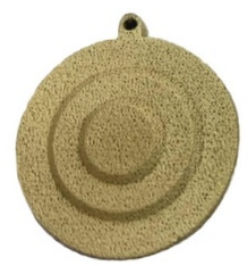

D12

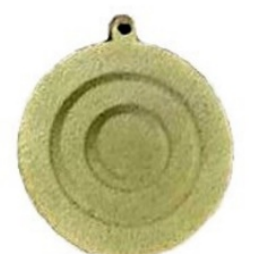

S22

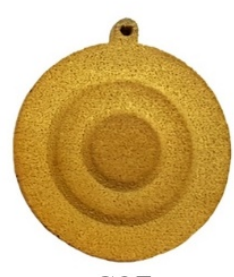

S27

Figure 4. Printed LPBF AlSi10Mg disk specimens: as printed specimen (upper left) and coated specimens with Au-Ag film. Specimens D10-D12 were coated at $80^{\circ} \mathrm{C}$, with 1:1 Ag/Au molar ratio of solution; specimens S19 and S21-S23 were coated at $80^{\circ} \mathrm{C}$, with 1:2 Ag/Au molar ratio of solution; and S24-S27 were coated at $90^{\circ} \mathrm{C}$, with $1: 2 \mathrm{Ag} / \mathrm{Au}$ molar ratio of solution.

\subsection{Characterization of the Au-Ag Coating}

The specimens were weighed before cleaning, after cleaning and etching, and after they were coated with $\mathrm{NiP}$ interlayer and $\mathrm{Au}-\mathrm{Ag}$ alloy. The measurements were performed by an analical balance (MRC ASB-220-C2) with a precision scale of $\pm 0.0001 \mathrm{~g}$.

To characterize the surface of the 3D-printed AlSi10Mg specimens before and after electrum coating, the following techniques were used:

(a) A qualitative pilling test was applied to all coated specimens with transparent vinyl tape to estimate the quality of the electrum coating adhesion.

(b) Optical light microscopy (Zeiss, Oberkochen, Germany) was used to observe the overall quality of the printed surface and to detect microscopic level discontinuities and defects.

(c) Roughness measurements were performed with Alpha-Step D-500 Stylus Profilometer optical profilometer (OP, KLA Tencor Ltd., Milpitas, CA, USA), with $0.1 \mathrm{~nm}$ vertical high-resolution profiling. Average value of surface roughness (7-10 measurements) was taken into consideration.

(d) The thickness of the NiP interlayer and electrum layer was measured by a calibrated high-resolution XRF (FISCHERSCOPE XRAY XDL 230, Fischer Technology Inc., Windsor, CT, USA) instrument (Table 3). The examined area in each measurement was a $\sim 1 \mathrm{~mm}$ circle in diameter. Each measurement was performed for $30 \mathrm{~s}$.

(e) X-ray diffraction (XRD) analysis was performed with a powder PANalytical Empyrean X-ray diffractometer (Malvern Panalytical Ltd, Malvern, UK) to determine the crystal structure of the films. Data was collected in the conventional symmetrical Bragg-Brentano configuration $(\theta / \theta)$ by means of $\mathrm{Cu} \mathrm{K} \alpha$ radiation $(\lambda=1.541 \AA)$ at $40 \mathrm{kV}$ and $30 \mathrm{~mA}$. Phase identification from the received XRD data was made using Pearson's handbook and ICDD data bases $[47,48]$. The evaluation of microstructure was done with the assistance of a Powder Cell Program [49]. 
(f) Focused ion beam (FIB) technology was applied with machine equipped with a high-resolution scanning electron microscope (SEM) in order to detect the cross-section of the electrum-plated specimen. Before excavating into the metal layers, a platinum wall was deposited by SEM (with voltage of $2.0 \mathrm{kV}$ and current of $2.7 \mathrm{nA}$ ). The FIB digging was performed with a high voltage of $30.0 \mathrm{kV}$ and a beam current of $21.0 \mathrm{nA}$, followed by etching the wall with a beam current of $6.5 \mathrm{nA}$. The FIB's cut dimensions are: $15 \mu \mathrm{m} \times 15 \mu \mathrm{m}$ with a depth of about $7 \mu \mathrm{m}$.

(g) X-ray photoelectron spectroscopy (XPS) measurements were performed in an ultra-high vacuum (UHV) of $2.5 \times 10^{-10}$ Torr base pressure, using 5600 Multi-Technique System (Physical Electronics (PHI), Chanhassen, MN, USA). The specimen was irradiated with an $\mathrm{Al} \mathrm{K} \alpha$ monochromatic source $(1486.6 \mathrm{eV})$. The outcome electrons were analyzed by a spherical capacitor analyzer using the slit aperture of $0.8 \mathrm{~mm}$. The specimens were not charged during measurements. The sputtering of the specimens was done using a $4 \mathrm{kV} \mathrm{Ar}+$ Ion Gun (sputter rate was $17 \AA / \mathrm{min}$ on $\mathrm{SiO}_{2} / \mathrm{Si}$ and was supposed to be about three times higher on $\mathrm{Au}-\mathrm{Ag})$.

Table 3. AM-LPBF AlSi10Mg disk-shaped specimens, the ELD process parameters, and the thickness of the coating (NiP interlayer and the Au-Ag electroless deposited layer). This XRF tool provides thickness measurements with an approximation error of $\pm 0.1 \mu \mathrm{m}$. Each XRF value is an average of three measurements.

\begin{tabular}{cccccc}
\hline Specimen No. & $\begin{array}{c}\text { Ag/Au Molar } \\
\text { Ratio of } \\
\text { Solution }\end{array}$ & $\begin{array}{c}\text { Temperature } \\
\left({ }^{\circ} \mathbf{C}\right)\end{array}$ & $\begin{array}{c}\text { ELD Time } \\
(\mathbf{m i n})\end{array}$ & \multicolumn{2}{c}{$\begin{array}{c}\text { Average Thickness }(\mu \mathrm{m}) \\
\text { XRF Measurement }\end{array}$} \\
\cline { 5 - 6 } D12 & $1: 1$ & 80 & 0.5 & 2.6 & 0.10 \\
\hline D11 & $1: 1$ & 80 & 1 & 2.3 & 0.11 \\
\hline D10 & $1: 1$ & 80 & 2 & 3.1 & 0.15 \\
\hline S19 & $1: 2$ & 80 & 1.5 & 5.7 & 0.12 \\
\hline S21 & $1: 2$ & 80 & 3 & 5.7 & 0.13 \\
\hline S23 & $1: 2$ & 80 & 5 & 5.4 & 0.13 \\
\hline S22 & $1: 2$ & 80 & 7 & 5.7 & 0.14 \\
\hline S25 & $1: 2$ & 90 & 3 & 4.1 & 0.15 \\
\hline S26 & $1: 2$ & 90 & 4 & 4.7 & 0.23 \\
\hline S24 & $1: 2$ & 90 & 6 & 4.2 & 0.36 \\
\hline S27 & $1: 2$ & 90 & 9 & 4.8 & 0.36 \\
\hline
\end{tabular}

\section{Results and Discussion}

\subsection{AM-LPBF AlSi10Mg Disk-Shaped Specimens}

Visual testing (VT) observation of the as-printed AlSi10Mg disk-shaped specimens revealed very rough topography (Figures $2 \mathrm{c}$ and $4 \mathrm{a}$ ), as expected for vertical surfaces of AM-LPBF AlSi10Mg as-printed specimens $[50,51]$.

The LM observation of the AlSi10Mg 3D-printed specimens also demonstrated that the surfaces are relatively rough and slightly porous (Figure $5 \mathrm{a}, \mathrm{e}, \mathrm{f})$. The as-printed average measured surface roughness of the AlSi10Mg specimens was $21 \mu \mathrm{m}$, according to the root mean square (RMS) method and $17 \mu \mathrm{m}$ according to the analytical function $(\mathrm{Ra})$ method. The results are in good agreement with typical values from the literature [51]. 

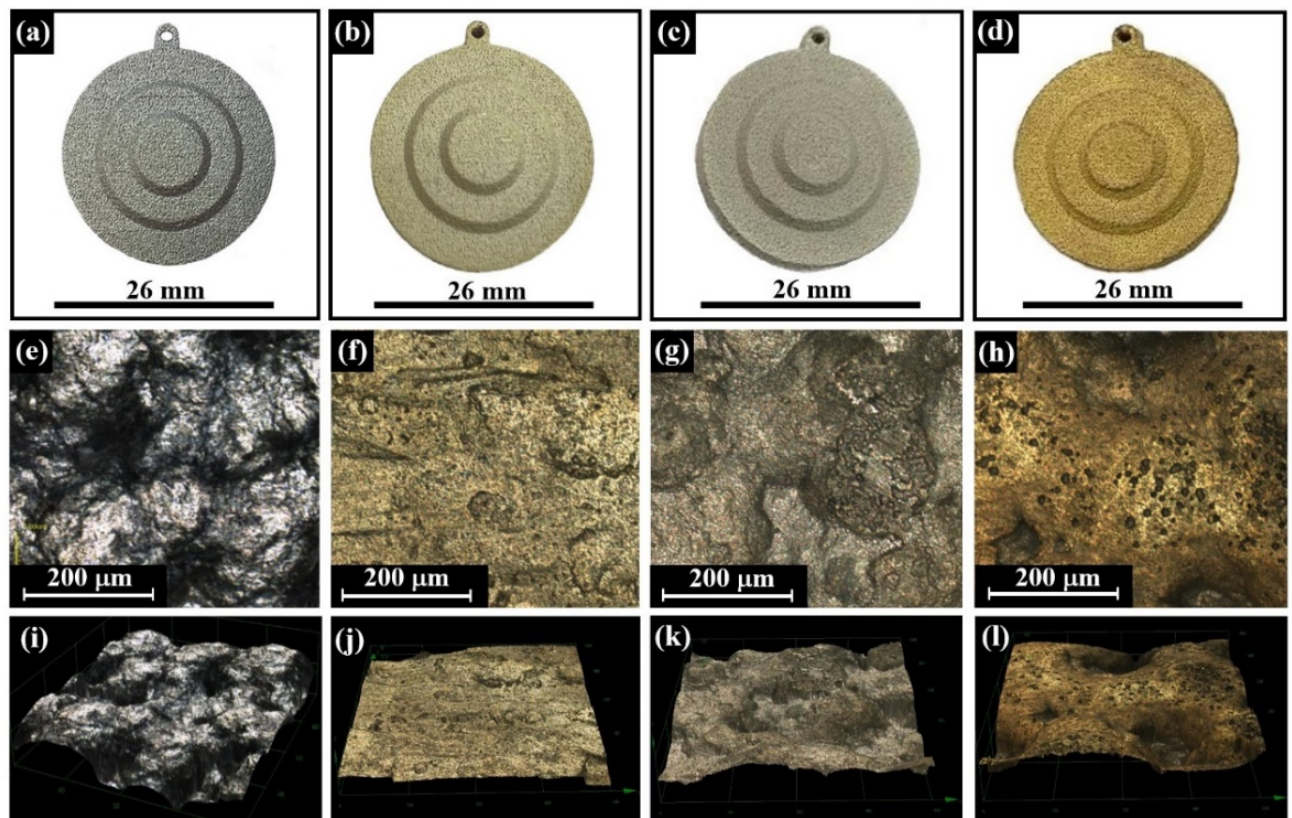

Figure 5. Optical images of the 3D-printed LPBF AlSi10Mg disk-shaped specimens (Table 1): (a) reference (as-printed) specimen; $(\mathbf{b})$ specimen D11 $\left(80^{\circ} \mathrm{C}\right)$; (c) specimen S23 $\left(80^{\circ} \mathrm{C}\right)$; (d) specimen S25 $\left(90^{\circ} \mathrm{C}\right) ;(\mathbf{e}-\mathbf{h}) 2 \mathrm{D}$ LM images of the reference, D11, S23, and S25 specimens, respectively; and (i-1) 3D LM images of the reference, D11, S23, and S25 specimens, respectively.

The XRD analysis of the LPBF as-printed AlSi10Mg specimens (Figure 6) revealed characteristic peaks of crystalline aluminum and silicon, where the $\mathrm{Al}$ is the major phase and $\mathrm{Si}$ is the minor phase. Characteristic peaks of Mg-base phases were not detected since AlSi10Mg alloy contains only up to $0.5 \mathrm{wt} \% \mathrm{Mg}$ [21].

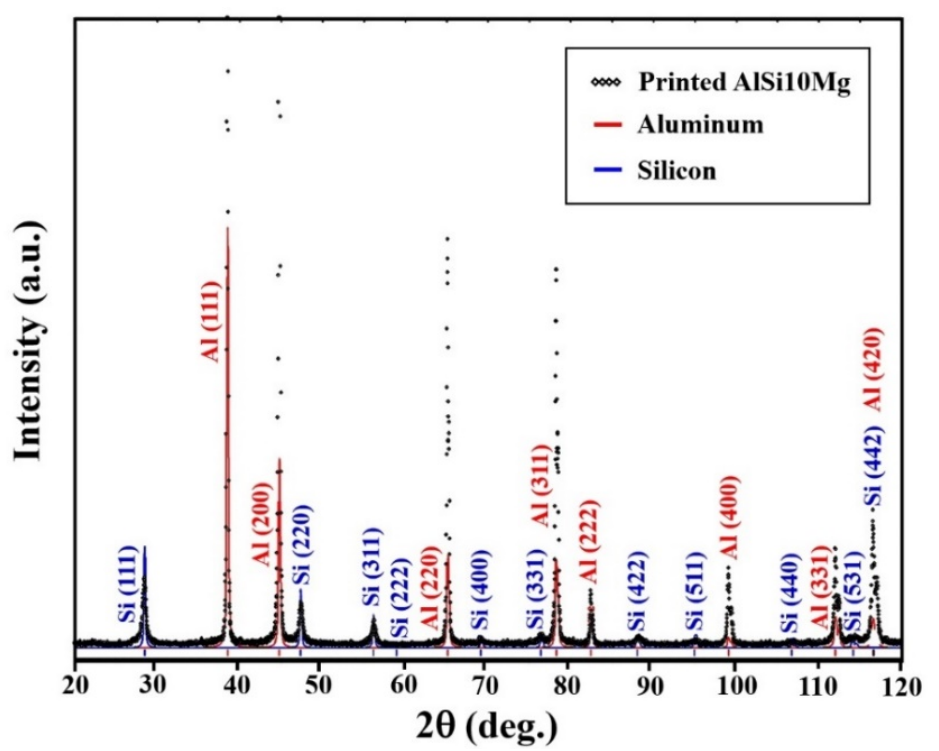

Figure 6. X-ray diffraction patterns of the as-printed AlSi10Mg substrate sample.

\subsection{Electroless Coating of Electrum on Top of AM-LPBF AlSi10Mg Disk-Shaped Specimens}

VT and LM examinations of the Au-Ag coated disk-shaped specimens (Figures 4 and 5, respectively) revealed uniform shiny metal surfaces, with rough topography. Specimens D10-D12 (1:1 Ag/Au molar ratio of solution) and specimens S19, S21-S23 (1:2 Ag/Au molar ratio of solution), both produced at $80^{\circ} \mathrm{C}$ (Table 3), were coated with a shiny grey-silver color metal. Specimens S24-S27 
(1:2 Ag/Au molar ratio of solution), produced at $90^{\circ} \mathrm{C}$ (Table 3), were coated with shiny yellow-gold color metal.

The qualitative pilling test of the electrum coated specimens revealed high-quality adhesion. At the macroscopic level, the rough topography was observed at the coated specimens (Figure 4). Yet the coated specimens were slightly less rough than the as-printed (un-coated) ones.

The XRD technique was used for phase identification of the electrum coated AlSi10Mg printed samples (D11, S22, and S24) and for the electrum lattice parameter calculations (Figure 7). Gold and silver create continuous series of disordered metallic-solid solutions at temperatures below the solidus, although a limited, short-range ordering was observed in the 50 at \% alloy [42,52].

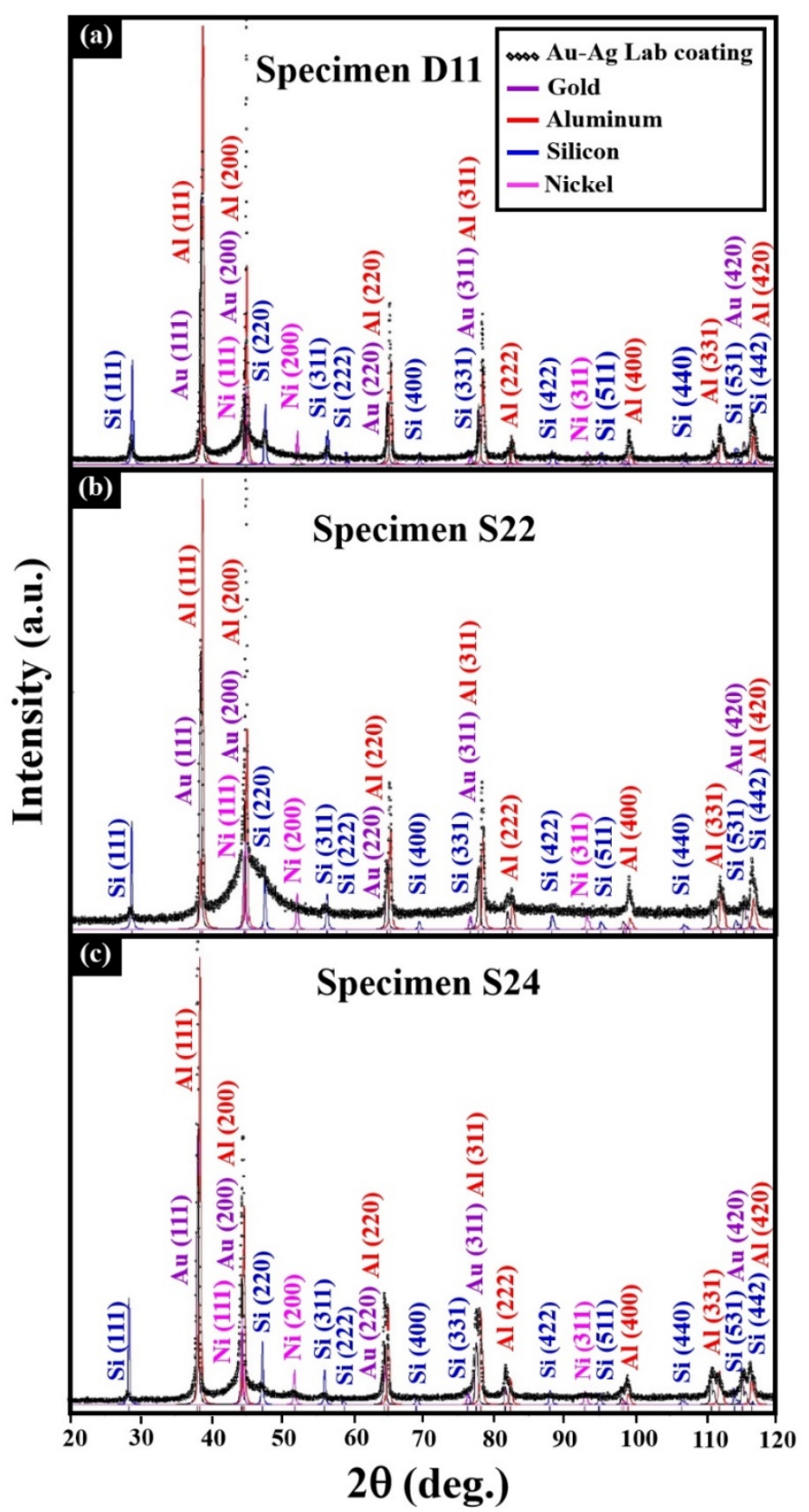

Figure 7. X-ray diffraction patterns of the Au-Ag coated specimens: (a) D11 $\left(80{ }^{\circ} \mathrm{C}\right)$; (b) S22 $\left(80{ }^{\circ} \mathrm{C}\right)$; and (c) S24 $\left(90^{\circ} \mathrm{C}\right)$.

A notable feature of $\mathrm{Au}-\mathrm{Ag}$ system is that a negative deviation from Vegard's law continues through all the concentration range. This results from the electronic interactions occurring between 
the external electron shells of the solute metal atoms and the neighboring solvent metal atoms [42]. The main results of the X-ray diffraction pattern (Figure 7) analysis for the three coated specimens are presented in Table 4. The NiP interlayer, deposited on D11 and S22 disk-shaped samples $\left(80^{\circ} \mathrm{C}\right)$, displays a disordered atomic-scale quasi-amorphous structure (a nano-crystalline materials with crystals below the threshold of yielding diffraction), whereas the interlayer on S24 sample $\left(90{ }^{\circ} \mathrm{C}\right)$ exhibits a mix of quasi-amorphous and nanocrystalline structure. The negative deviation of the electrum lattice parameter from Vegard's law is clearly observed in all three analyzed samples.

Table 4. Phase identification and electrum lattice parameter for the D11 $\left(80{ }^{\circ} \mathrm{C}\right), \mathrm{S} 22\left(80^{\circ} \mathrm{C}\right)$, and S24 $\left(90{ }^{\circ} \mathrm{C}\right) \mathrm{Au}-\mathrm{Ag}$ coated specimens.

\begin{tabular}{|c|c|c|c|c|}
\hline Specimen & $\begin{array}{c}\text { Lattice Parameter } \\
\text { (§) }\end{array}$ & $\begin{array}{l}\text { Characteristics of the } \\
\text { Electrum (Au-Ag) } \\
\text { Coating }\end{array}$ & $\begin{array}{c}\text { Characteristics of } \\
\text { the } \mathrm{Ni}-\mathrm{P} \\
\text { Interlayer }\end{array}$ & $\begin{array}{c}\text { Characteristics of } \\
\text { the Printed } \\
\text { Substrate }\end{array}$ \\
\hline D11 & $4.080( \pm 0.001)$ & \multirow{2}{*}{$\begin{array}{c}\text { Rich in Ag, } \\
\text { solid-solution crystalline } \\
\text { phase }\end{array}$} & \multirow{2}{*}{ Quasi-amorphous } & \multirow{3}{*}{$\begin{array}{c}\text { Major crystalline } \\
\text { phase Al } \\
\text { Minor crystalline } \\
\text { phase Si }\end{array}$} \\
\hline $\mathrm{S} 22$ & $4.079( \pm 0.001)$ & & & \\
\hline S24 & $4.076( \pm 0.001)$ & $\begin{array}{c}\text { Rich in } \mathrm{Au}, \\
\text { solid-solution crystalline } \\
\text { phase }\end{array}$ & $\begin{array}{c}\text { Mix of } \\
\text { quasi-amorphous } \\
\text { and nanocrystalline }\end{array}$ & \\
\hline
\end{tabular}

Without Ni (Figure 6), there is a uniform normal small background at all $2 \theta$ range. However, in samples D11, S22, and S24 there is a broad peak around the location of (111) diffraction line of nickel. Since Ni is reported to form amorphous layer in electroless coating [53-56], this broad line is attribute to scattering of quasi-amorphous $\mathrm{Ni}$ as severely broaden peak of the strongest diffraction line. However, in S24 the Ni (200) reflection was also identified in addition to (111) broad peak. It is assumed that (200) is a reflection of nano-crystalline Ni. From the ratio of (111) and (200) peaks' areas it was found that the area of (111) is above the expected intensity of the Ni polycrystalline substance. Excluding preferred orientation case it is reasonable to assume for S24 sample a mixture of quasi-amorphous and nano-crystalline material.

A combination of quasi-amorphous and nanocrystalline structure is quite familiar phenomenon for electroless deposited NiP interlayers. This deposition is applied at relatively low temperatures $\left(<100^{\circ} \mathrm{C}\right)$, hence the crystallization around nucleation centers occurs at low rate. The activation energies for crystallization depend on the defects and imperfections within the grains' boundaries. Therefore, when the temperature increases the tendency for crystalline structure also increases. Upon heat treatment quasi-amorphous gradually becomes crystalline and grain growth will occur [53-56]. In amorphous materials like glass the grain boundaries are de localized, or in other words there are no grain boundaries, therefore the materials stay amorphous until melting.

The measured mass values of the coating (NiP and electrum layers) were between 0.0124-0.0437 g. The mass of the electrum coating (after eliminating the mass of the NiP interlayer) was increased significantly during the first 3-4 min of the deposition process (Figure 8a). 

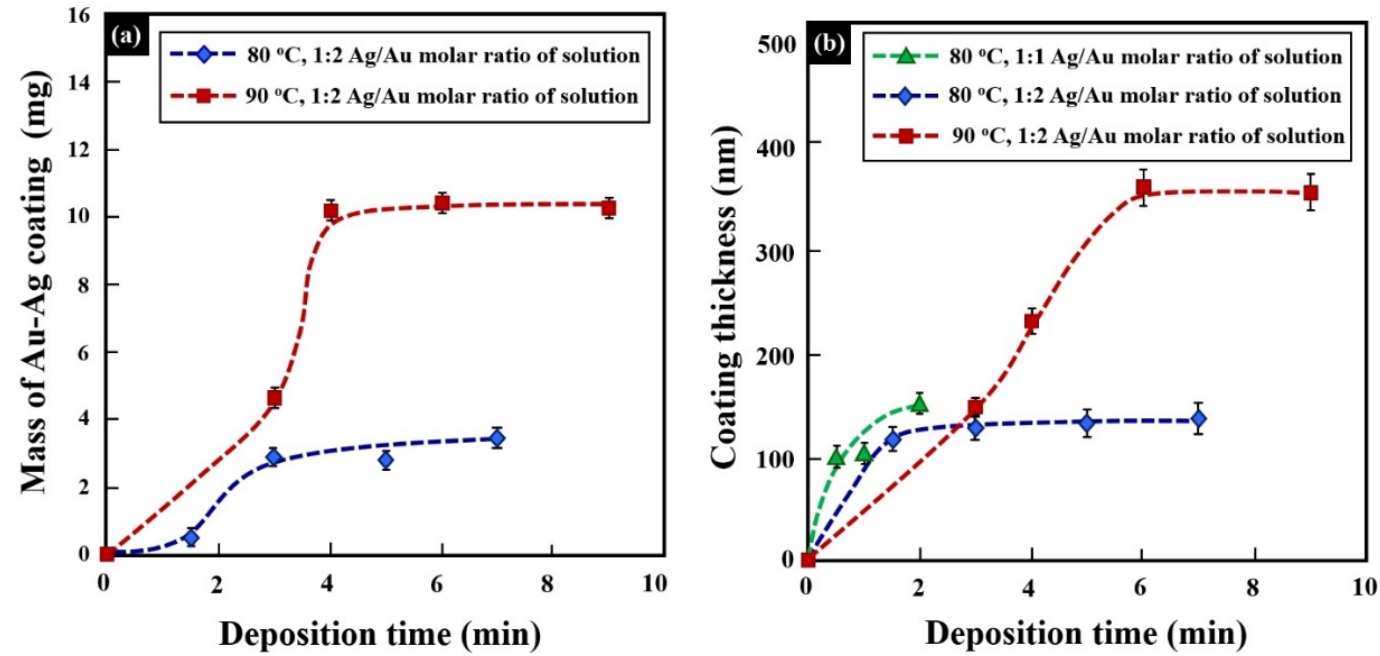

Figure 8. Gold-silver electroless plating, measured for 80 and $90{ }^{\circ} \mathrm{C}$ deposition temperatures: (a) mass of the $\mathrm{Au}-\mathrm{Ag}$ coating versus deposition time after eliminating the mass of the deposited NiP interlayer); and (b) thickness of the Au-Ag coating (measured by XRF) versus deposition time.

The average RMS and Ra surface roughness values of the coated specimens, measured by an OP instrument, were slightly lower than the ones of the as-printed specimens (Figure 9). This may be due to partial surface smoothing of the printed alloy surface by the NiP interlayer. Furthermore, both the RMS and Ra roughness values were reduced when the deposition time was increased (Figure 9). This evidence is known for thin metal film electroless deposition and may be explained by the specific adsorption of the solution components such as reducing or complexing agents on the activated surface that results in surface smoothing by the growing coating [21,57].
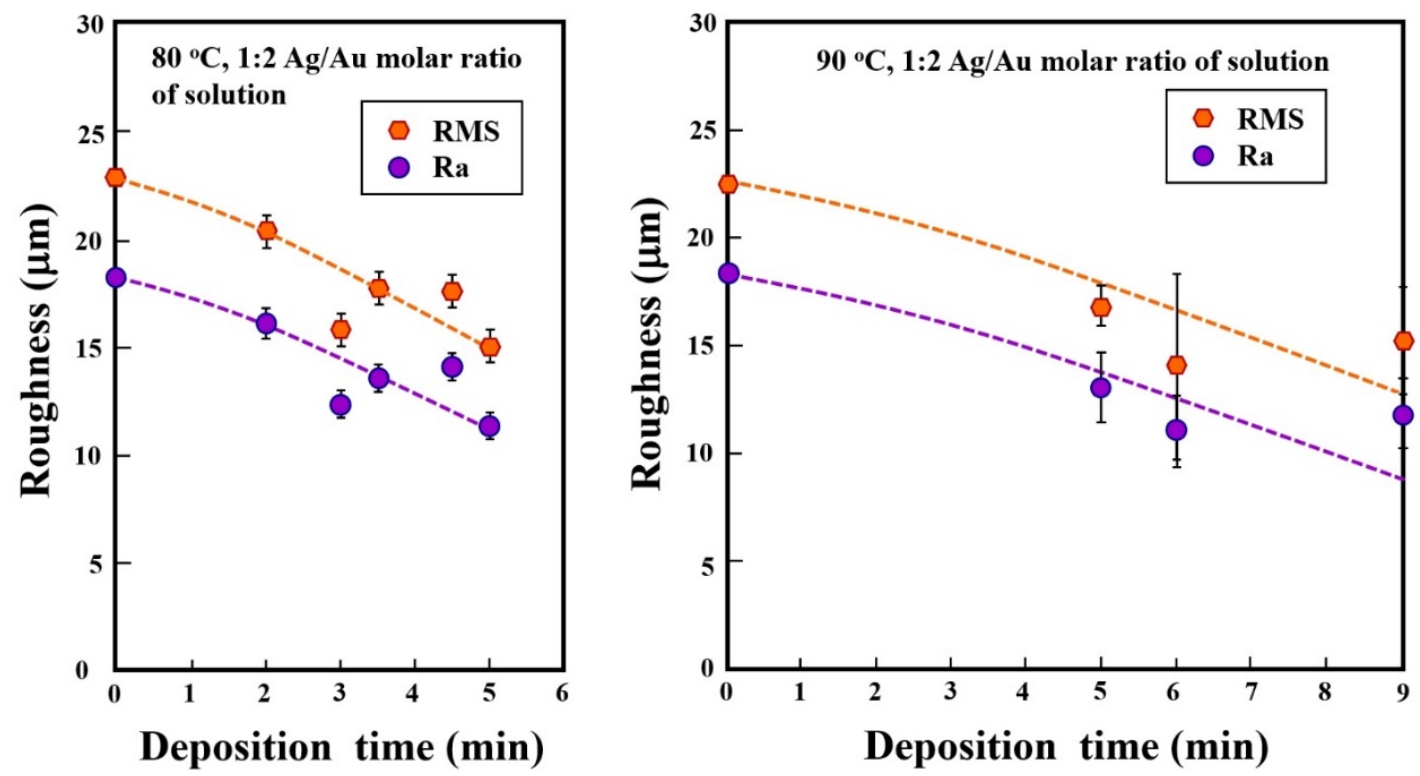

Figure 9. Roughness of the printed LPBF AlSi10Mg disk-shaped specimens covered with $\mathrm{Au}-\mathrm{Ag}$ coating versus coating time, as measured by OP.

It is important to note that the thickness of the deposited films (NiP interlayer and the electrum coating layer) are both well below the average surface roughness of the as-printed specimens (Figure 9). Therefore, at the macroscopic level, the surface appearance of the coated specimens remained close to the initial as-printed specimens (Figure 9). According to the XRF measurements, the thickness of the NiP interlayer was between $2.3 \mu \mathrm{m}$ and $5.7 \mu \mathrm{m}$. In order to measure the thickness of the 
coated specimens, the estimated density of each specimen was calculated based on the composition measured by XPS. The measured thickness of the coated electrum layer was between $0.1 \mu \mathrm{m}$ (for the D12 specimen, $80{ }^{\circ} \mathrm{C}, 0.5 \mathrm{~min}$ deposition) and $0.4 \mu \mathrm{m}$ (for the $\mathrm{D} 24$ specimen, $90{ }^{\circ} \mathrm{C}, 9 \mathrm{~min}$ deposition) (Table 1, Figure $8 \mathrm{~b}$ ). The thickness of the electrum film was increased as the temperature and process time increased (Figure 8b).

Conventional metallographic cross-sections of the electrum coated specimens could not be performed since the electrum film is too soft, ductile and very thin (up to $0.363 \mu \mathrm{m}$ according to the XRF measurements). Therefore, a FIB-SEM cross-section examination for the D11 coated specimen was performed (Figure 10). A relatively uniform electrum film, with average thickness of $\sim 0.1 \mu \mathrm{m}$, was achieved mostly due to the presence of NiP interlayer (Figure 10).
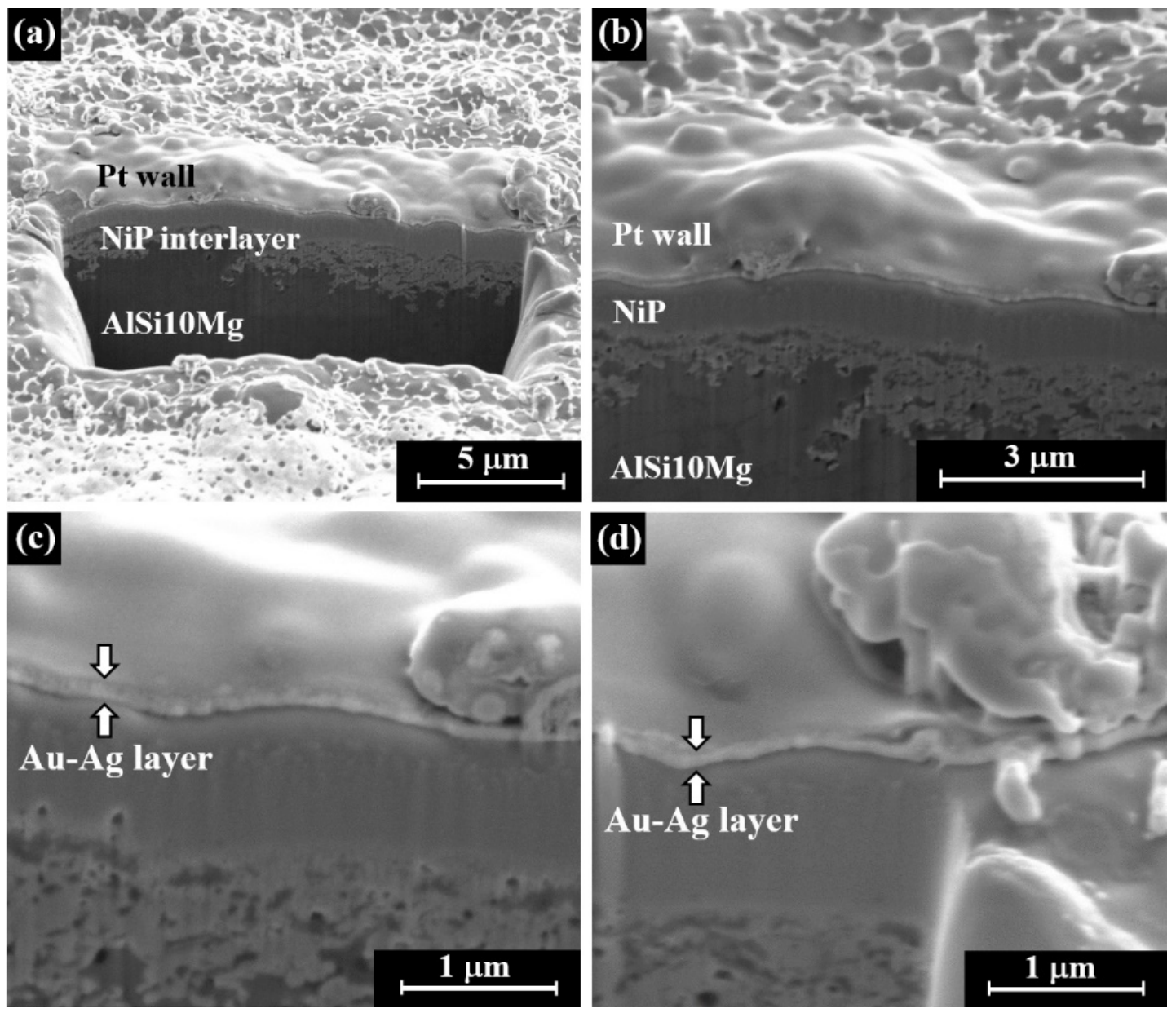

Figure 10. SEM images of the Au-Ag plated AlSi10Mg D11 specimen (deposited at $80{ }^{\circ} \mathrm{C}$ ) after selectively milling material from the specimen surface with FIB technology: (a) the hole cut by FIB and the Pt wall behind; and (b-d) the coated specimen's cross-section, showing the $1 \mu \mathrm{m} \mathrm{NiP}(\sim 5 \mathrm{wt} \% \mathrm{P})$ layer and the $\mathrm{Au}-\mathrm{Ag}$ layer on top (bright area).

According to the XPS profile analysis the thickness of the electrum layer after 3 min of deposition is about $0.1 \mu \mathrm{m}$ and $0.25 \mu \mathrm{m}$ for the 80 and $90^{\circ} \mathrm{C}$, respectively (Figure $11 \mathrm{~b}, \mathrm{c}$ ). The thickness measurements revealed a similar magnitude of results for the XRF, FIB-SEM, and XPS techniques (Table 1, Figures 10 and 11). 

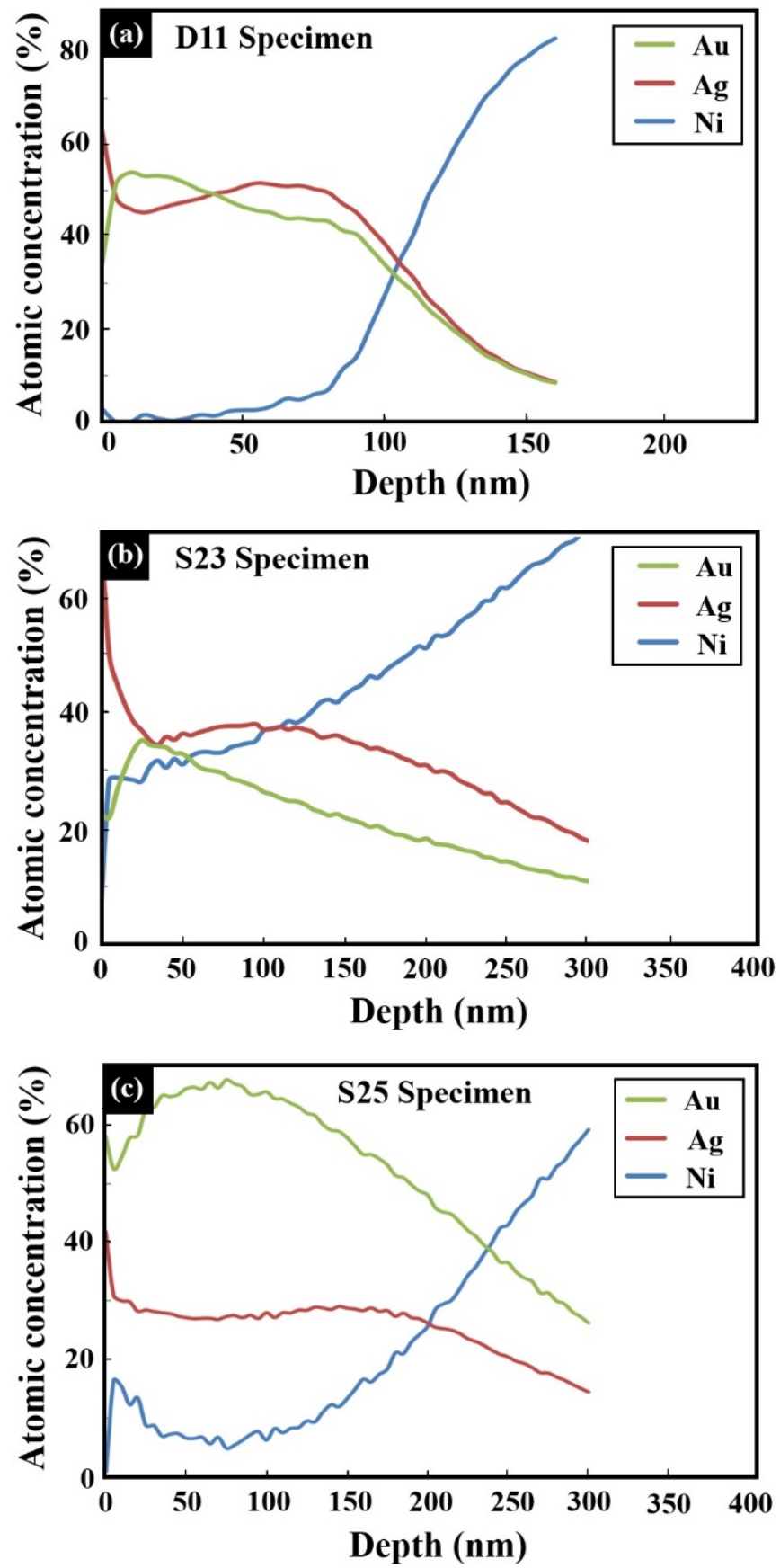

Figure 11. XPS elemental analysis at \% profile of the Au-Ag coated layer cross-section: (a) D11 $\left(80{ }^{\circ} \mathrm{C}\right)$ specimen; (b) S23 $\left(80^{\circ} \mathrm{C}\right)$ specimen; and (c) S25 $\left(90^{\circ} \mathrm{C}\right)$ specimen.

High processing temperature significantly increases the film deposition rate that enables production of thicker electrum coatings (Figure 11). The alloy deposition rate at $90{ }^{\circ} \mathrm{C}$ is about $5 \mathrm{mg} / \mathrm{min}$; this value is about four times higher than that at $80^{\circ} \mathrm{C}(\sim 1.3 \mathrm{mg} / \mathrm{min})$ (Figure 7). Moreover, the temperature also influences the composition of the Ag-Au coating by increasing the Au content (Figure 11b,c). According to the XPS analysis before sputtering (external surface of the coating); the film deposited at $80{ }^{\circ} \mathrm{C}$ consisted of about 20 at \% Au (specimen S23), while about 60 at \% Au was determined at the layer deposited at $90{ }^{\circ} \mathrm{C}$ (specimen S25). XPS depth profiling of the coatings (Figure 9) presents distribution of the alloying elements during the film growth and illustrates different mechanism of the $\mathrm{Ag}-\mathrm{Au}$ formation at temperatures 80 and $90^{\circ} \mathrm{C}$ (Figure 11a-c). Gold is a nobler metal than silver (electrochemical potentials are $-0.61 \mathrm{~V}$ and $-0.29 \mathrm{~V}$, respectively). Moreover, the binding energy of 
$\mathrm{Au}-\mathrm{Ni}, \mathrm{Au}-\mathrm{Au}, \mathrm{Ag}-\mathrm{Ag}$, and $\mathrm{Ag}-\mathrm{Au}$ is $247 \mathrm{~kJ} \cdot \mathrm{mol}^{-1}, 226 \mathrm{~kJ} \cdot \mathrm{mol}^{-1}, 162.9 \mathrm{~kJ} \cdot \mathrm{mol}^{-1}$ and $202.5 \mathrm{~kJ} \cdot \mathrm{mol}^{-1}$, respectively [58,59]. All this demonstrates that compared to Ag, significantly higher activation energy is needed to start reduction of $\mathrm{Au}$ ions and form gold coating. Thus, formation of an Ag film on the Ni surface is preferable. This is confirmed by data presented in Figure 11a-b. At the beginning of the deposition process, at $80{ }^{\circ} \mathrm{C}$, independently on an $\mathrm{Ag} / \mathrm{Au}$ molar ratio of solution, the $\mathrm{Ag}$ reduction is dominant and its content on the interface is higher than the Au. After coverage of the Ni surface by silver, it catalyzes the gold reduction that results in the formation of $\mathrm{Ag}-\mathrm{Au}$ bonding and causes intensive incorporation of the Au into the coating. Nevertheless, all $\mathrm{Au}-\mathrm{Ag}$ alloys prepared at $80{ }^{\circ} \mathrm{C}$ have consisted of $65-67$ at \% Ag and have demonstrated a silvered appearance (Figure 4). At $90{ }^{\circ} \mathrm{C}$, gold appears on the interface from the beginning of the process, and its content in the alloy increases during film growth and achieves 60-65 at \% (Figure 11c). Those Au-Ag alloys have a goldish color (Figure 4). It should be noted that equal concentrations of alloying metals in a solution allows for a deposition of dense and relatively homogeneous electrum coatings (Figure 11a). However, independent of temperature, porous and corrugated films have been created from the 1:2 Ag/Au molar ratio solution (Figures 4 and 11b,c). This is beyond the scope of present study and will be the subject of future investigation.

The suggested coating technology needs simple equipment and therefore it is relatively low cost process. Moreover, it is environmentally friendly and low temperature process, which allows coating of conductive and nonconductive surfaces without damage. However, some aspects of the $\mathrm{Au}-\mathrm{Ag}$ electroless coatings process of AM-LPBF AlSi10Mg were not studied in this work, such as the influence of residual stresses and internal mesostructures on the coating quality, as well as the quality of the coating after long period of use in different environments, and will be matter of the future investigation.

\section{Conclusions}

In the current study, a simple to use environmentally friendly electroless Au-Ag plating was developed and applied to AM-LPBF AlSi10Mg specimens for the first time in order to improve the surface appearance based on aesthetic considerations. A significant advantage of the developed electroless electrum coating process is the avoidance of environmentally hazardous material such as cyanide chemical compounds, low processing temperature, and low cost. It was necessary to develop a special electroless process suitable for the cover of 3D-printed AlSi10Mg, where the external surface is highly hydrophobic and rough. The influence of the deposition time on the Au-Ag coating thickness and its roughness was examined at two different processing temperatures $\left(80\right.$ and $\left.90^{\circ} \mathrm{C}\right)$. The results displayed good quality and a satisfactorily shiny appearance for $\mathrm{Au}-\mathrm{Ag}$ coating surfaces for both temperatures. The roughness of the $\mathrm{Au}-\mathrm{Ag}$ plated specimens was somewhat reduced as the thickness of the $\mathrm{Au}-\mathrm{Ag}$ film was increased. Yet coatings prepared at $80^{\circ} \mathrm{C}$ have a silver metal appearance and consist of $65-67$ at $\% \mathrm{Ag}$, while at $90{ }^{\circ} \mathrm{C}$, deposits have a gold metal appearance and a content of 60-65 at \% Au. Phase identification and lattice parameter of the electrum coated specimens were achieved by XRD analysis. The results revealed that the electrum coatings were composed of $\mathrm{Au}-\mathrm{Ag}$ crystalline phases (rich in $\mathrm{Ag}$ or $\mathrm{Au}$ ) over a Ni-P interlayer made of quasi-amorphous, or mixed quasi-amorphous and nanocrystalline. In all examined electrum coated specimens, negative deviation of the electrum lattice parameter of Vegard's law was observed. The temperature and metal concentration dependence of the mechanism of $\mathrm{Ag}-\mathrm{Au}$ alloy formation was studied based on an XPS analysis. It was shown that at a low temperature, the Ag was dominant at the beginning of the deposition process, while at $90^{\circ} \mathrm{C}$ the Au was first detected on the interface. This effect was explained by electrochemical properties of alloying metals and the binding energies needed to form Me-Ni and $\mathrm{Ag}-\mathrm{Au}$ bonding. It was observed that dense and relatively homogeneous $\mathrm{Au}-\mathrm{Ag}$ coatings were deposited from solutions with equal concentration of alloying metals, while defective (porous and relatively corrugated) films were prepared from the solution with a 1:2 Ag/Au molar ratio of solution. Based on the XRF and FIB-SEM measurements, the thickness of the NiP interlayer was 2.3-5.7 $\mu \mathrm{m}$. Based on the XRF, FIB-SEM and XPS, the thickness of the Au-Ag film was 0.1-0.4 $\mu \mathrm{m}$, increasing 
with deposition time and processing temperatures. The current developed electroless $\mathrm{Au}-\mathrm{Ag}$ coating process can be adapted to various applications, including 3D printed items for museum exhibitions.

Author Contributions: All authors defined the research aims and contributed to the development of the research methodology. A.S. wrote the 'Additive Manufacturing' part of the Introduction, A.I. and Y.S.-D. wrote the 'Electroless Plating of Gold-silver Alloy' part of the Introduction, and D.A. wrote the 'Electrum Alloy' part of the Introduction. A.S. was in charge of the production of the AM-LPBF AlSi10Mg specimens. A.I. and Y.S.-D. developed the $\mathrm{Au}-\mathrm{Ag}$ coatings, and A.I. prepared the electroless $\mathrm{Au}-\mathrm{Ag}$ coatings and was in charge of the 'Materials and Experimental Methods' part, and G.K. was in charge of the XRD analysis. A.S. and D.A. were in charge of the structure of the publication and D.A. had supervision on the manuscript and was in charge of the figures. All authors discussed the results and contributed to the conclusions. All authors discussed the results and contributed to the conclusions, as well as reviewed the manuscript and agreed to publish this version. All authors have read and agreed to the published version of the manuscript.

Funding: The author did not receive any specific funding for this work.

Acknowledgments: The study was supported by the Tel Aviv University and the Afeka Academic College of Engineering to whom the authors are thankful. The authors would also like to thank Barak Noy from the Afeka Academic College of Engineering for his technical assistance, and Maria Tkachev and Yafit Fleger, from the Institute of Nanotechnology and Advanced Materials, Bar Ilan University, for their assistance with the FIB-SEM instrument measurements. Thanks are also due to Barbara Doron for the English editing.

Conflicts of Interest: The authors declare no conflict of interest.

\section{References}

1. Herzog, D.; Seyda, V.; Wycisk, E.; Emmelmann, C. Additive manufacturing of metals. Acta Mater. 2016, 117, 371-392. [CrossRef]

2. Steuben, J.C.; Birnbaum, A.J.; Michopoulos, J.G.; Iliopoulos, A.P. Enriched analytical solutions for additive manufacturing modeling and simulation. Add. Manuf. 2019, 25, 437-447. [CrossRef]

3. Han, Q.; Gu, H.; Soe, S.; Setchi, R.; Lacan, F.; Hill, J. Manufacturability of AlSi10Mg overhang structures fabricated by laser powder bed fusion. Mater. Des. 2018, 160, 1080-1095. [CrossRef]

4. Whip, B.; Sheridan, L.; Gockel, J. The effect of primary processing parameters on surface roughness in laser powder bed additive manufacturing. Int. J. Adv. Manuf. Technol. 2019, 103, 4411-4422. [CrossRef]

5. Sagbas, B. Post-processing effects on surface properties of direct metal laser sintered AlSi10Mg parts. Met. Mater. Int. 2020, 26, 143-153. [CrossRef]

6. Russell, R.; Wells, D.; Waller, J.; Poorganji, B.; Ott, E.; Nakagawa, T.; Sandoval, H.; Shamsaei, N.; Seifi, M. Qualification and Certification of Metal Additive Manufactured Hardware for Aerospace Applications. In Additive Manufacturing for the Aerospace Industry, 1st ed.; Froes, F., Boyer, R., Eds.; Elsevier: Amsterdam, The Netherlands, 2019; pp. 33-66.

7. DebRoy, T.; Wei, H.L.; Zuback, J.S.; Mukherjee, T.; Elmer, J.W.; Milewski, J.O.; Beese, A.M.; Wilson-Heid, A.; De, A.; Zhang, W. Additive manufacturing of metallic components-process, structure and properties. Prog. Mater. Sci. 2018, 92, 112-224. [CrossRef]

8. Zhang, D.; Sun, S.; Qiu, D.; Gibson, M.A.; Dargusch, M.S.; Brandt, M.; Qian, M.; Easton, M. Metal alloys for fusion-based additive manufacturing. Adv. Eng. Mater. 2018, 20, 1700952. [CrossRef]

9. Hitzler, L.; Merkel, M.; Hall, W.; Öchsner, A. A review of metal fabricated with laser-and powder-bed based additive manufacturing techniques: Process, nomenclature, materials, achievable properties, and its utilization in the medical sector. Adv. Eng. Mater. 2018, 20, 1700658. [CrossRef]

10. Fiegl, T.; Franke, M.; Körner, C. Impact of build envelope on the properties of additive manufactured parts from AlSi10Mg. Opt. Laser Technol. 2019, 111, 51-57. [CrossRef]

11. Cabrini, M.; Lorenzi, S.; Pastore, T.; Testa, C.; Manfredi, D.; Lorusso, M.; Calignano, F.; Pavese, M.; Andreatta, F. Corrosion behavior of AlSi10Mg alloy produced by laser powder bed fusion under chloride exposure. Corros. Sci. 2019, 152, 101-108. [CrossRef]

12. Kok, Y.; Tan, X.P.; Wang, P.; Nai, M.L.S.; Loh, N.H.; Liu, E.; Tor, S.B. Anisotropy and heterogeneity of microstructure and mechanical properties in metal additive manufacturing: A critical review. Mater. Des. 2018, 139, 565-586. [CrossRef] 
13. Cabrini, M.; Lorenzi, S.; Testa, C.; Pastore, T.; Manfredi, D.; Lorusso, M.; Calignano, F.; Fino, P. Statistical approach for electrochemical evaluation of the effect of heat treatments on the corrosion resistance of AlSi10Mg alloy by laser powder bed fusion. Electrochim. Acta 2019, 305, 459-466. [CrossRef]

14. Cabrini, M.; Calignano, F.; Fino, P.; Lorenzi, S.; Lorusso, M.; Manfredi, D.; Testa, C.; Pastore, T. Corrosion behavior of heat-treated AlSi10Mg manufactured by laser powder bed fusion. Materials 2018, 11, 1051. [CrossRef] [PubMed]

15. Li, B.Q.; Li, Z.; Bai, P.; Liu, B.; Kuai, Z. Research on surface roughness of AlSi10Mg parts fabricated by laser powder bed fusion. Metals 2018, 8, 524. [CrossRef]

16. Maamoun, A.; Xue, Y.; Elbestawi, M.; Veldhuis, S. The effect of selective laser melting process parameters on the microstructure and mechanical properties of Al6061 and AlSi10Mg alloys. Materials 2019, 12, 12. [CrossRef]

17. Shukla, S.; Gomathi, N.; George, R. Autocatalytic silver-plating of aluminum radio frequency waveguides with autocatalytic nickel as the undercoat for space applications. Surf. Topogr. Metrol. Prop. 2014, 2, 045004. [CrossRef]

18. Rosenthal, I.; Shneck, R.; Stern, A. Heat treatment effect on the mechanical properties and fracture mechanism in AlSi10Mg fabricated by additive manufacturing selective laser melting process. Mater. Sci. Eng. A 2018, 729, 310-322. [CrossRef]

19. Casati, R.; Hamidi Nasab, M.; Coduri, M.; Tirelli, V.; Vedani, M. Effects of platform pre-heating and thermal-treatment strategies on properties of AlSi10Mg alloy processed by selective laser melting. Metals 2018, 8, 954. [CrossRef]

20. Peverini, O.A.; Addamo, G.; Lumia, M.; Virone, G.; Calignano, F.; Lorusso, M.; Manfredi, D. Additive manufacturing of $\mathrm{Ku} / \mathrm{K}$-band waveguide filters: A comparative analysis among selective-laser melting and stereo-lithography. IET Microw. Antennas Propag. 2017, 11, 1936-1942. [CrossRef]

21. Dresler, N.; Inberg, A.; Ashkenazi, D.; Shacham-Diamand, Y.; Stern, A. Silver electroless finishing of selective laser melting 3D-printed AlSi10Mg artifacts. Metallogr. Microstruct. Anal. 2019, 8, 678-692. [CrossRef]

22. Paunovic, M.; Schlesinger, M. Fundamentals of Electrochemical Deposition, 2nd ed.; John Wiley \& Sons: Hoboken, NJ, USA, 2006; pp. 140-145.

23. Asher, T.; Inberg, A.; Glickman, E.; Fishelson, N.; Shacham-Diamand, Y. Formation and characterization of low resistivity sub-100 nm copper films deposited by electroless on SAM. Electrochim. Acta 2009, 54, 6053-6057. [CrossRef]

24. Inberg, A.; Livshits, P.; Zalevsky, Z.; Shacham-Diamand, Y. Electroless deposition of silver thin films on gold nanoparticles catalyst for micro and nanoelectronics applications. Microelectron. Eng. 2012, 98, 570-573. [CrossRef]

25. Shacham-Diamand, Y.; Osaka, T.; Okinaka, Y.; Sugiyama, A.; Dubin, V. 30 years of electroless plating for semiconductor and polymer micro-systems. Microelectron. Eng. 2015, 132, 35-45. [CrossRef]

26. Fishelson, N.; Inberg, A.; Croitoru, N.; Shacham-Diamand, Y. Highly corrosion resistant bright silver metallization deposited from a neutral cyanide-free solution. Microelectron. Eng. 2012, 92, 126-129. [CrossRef]

27. Duhin, A.; Inberg, A.; Eliaz, N.; Gileadi, E. Electroless plating of rhenium-based alloys with nickel, cobalt and iron. Electrochim. Acta 2015, 174, 660-666. [CrossRef]

28. Wang, J.; Wu, Q. The effects of anodic interlayer on the morphology and mechanical performances of electroless Ni-P coating on Al alloy. Appl. Phys. A 2017, 123, 435. [CrossRef]

29. Szklarska-Smialowska, Z. Pitting corrosion of aluminum. Corros. Sci. 1999, 41, 1743-1767. [CrossRef]

30. Marquez, K.; Staikov, G.; Schultze, J.W. Electrochemical deposition of Ag, Au and Ag-Au alloys on Si(111). Trans. IMF 2002, 80, 73-78. [CrossRef]

31. Huang, T. Electrodeposited silver-gold alloys as a sensor for paracetamol determination. Int. J. Electrochem. Sci. 2017, 12, 11419-11427. [CrossRef]

32. Akben, K.; Timur, S. A study of gold-silver alloy electrodeposited from pyrophosphate-cyanide electrolyte using polyethylenimine-KSeCN additives. Int. J. Electrochem. Sci. 2018, 13, 3855-3873. [CrossRef]

33. Link, S.; Wang, Z.L.; El-Sayed, M.A. Alloy formation of gold-silver nanoparticles and the dependence of the plasmon absorption on their composition. J. Phys. Chem. B 1999, 103, 3529-3533. [CrossRef]

34. Shibata, T.; Bunker, B.A.; Zhang, Z.; Meisel, D.; Vardeman, C.F.; Gezelter, J.D. Size-dependent spontaneous alloying of Au-Ag nanoparticles. J. Am. Chem. Soc. 2002, 124, 11989-11996. [CrossRef] [PubMed] 
35. Liu, S.; Chen, G.; Prasad, P.N.; Swihart, M.T. Synthesis of monodisperse Au, Ag, and Au-Ag alloy nanoparticles with tunable size and surface plasmon resonance frequency. Chem. Mater. 2011, 23, 4098-4101. [CrossRef]

36. Zhang, Q.; Jing, H.; Li, G.G.; Lin, Y.; Blom, D.A.; Wang, H. Intertwining roles of silver ions, surfactants, and reducing agents in gold nanorod overgrowth: Pathway switch between silver underpotential deposition and gold-silver codeposition. Chem. Mater. 2016, 28, 2728-2741. [CrossRef]

37. Ahn, J.; Wang, D.; Ding, Y.; Zhang, J.; Qin, D. Site-selective carving and co-deposition: Transformation of Ag nanocubes into concave nanocrystals encased by Au-Ag alloy frames. ACS Nano 2018, 12, $298-307$. [CrossRef]

38. Okamoto, H.; Massalski, T.B. The Ag-Au (silver-gold) system. Bull. Alloy Phase Diagr. 1983, 4, 30-38. [CrossRef]

39. Ashkenazi, D.; Gitler, H.; Stern, A.; Tal, O. Archaeometallurgical characterization and manufacturing technologies of fourth century BCE silver jewelry: The Samaria and Nablus hoards as test case. Metallogr. Microstruct. Anal. 2018, 7, 387-413. [CrossRef]

40. Bond, G.C.; Thompson, D.T. Catalysis by gold. Catal. Rev. 1999, 41, 319-388. [CrossRef]

41. Krupp, R.E.; Weiser, T. On the stability of gold-silver alloys in the weathering environment. Miner. Depos. 1992, 27, 268-275. [CrossRef]

42. Lubarda, V.A. On the effective lattice parameter of binary alloys. Mech. Mater. 2003, 35, 53-68. [CrossRef]

43. Elliott, R.P.; Shunk, F.A. The Ag-Au (silver-gold) system. Bull. Alloy Phase Diagr. 1980, 1, 45-47. [CrossRef]

44. Hough, R.M.; Butt, C.R.; Fischer-Bühner, J. The crystallography, metallography and composition of gold. Elements 2009, 5, 297-302. [CrossRef]

45. Troalen, L.G.; Tate, J.; Guerra, M.F. Goldwork in Ancient Egypt: Workshop practices at Qurneh in the 2nd Intermediate Period. J. Archaeol. Sci. 2014, 50, 219-226. [CrossRef]

46. Guisbiers, G.; Mendoza-Cruz, R.; Bazán-Díaz, L.; Velázquez-Salazar, J.J.; Mendoza-Perez, R.; Robledo-Torres, J.A.; Rodriguez-Lopez, J.L.; Montejano-Carrizales, J.M.; Whetten, R.L.; José-Yacamán, M. Electrum, the gold-silver alloy, from the bulk scale to the nanoscale: Synthesis, properties, and segregation rules. ACS Nano 2015, 10, 188-198. [CrossRef] [PubMed]

47. File, P.D. Powder Diffraction Data; International Centre for Diffraction Data: Newtown Square, PA, USA, 1986.

48. Villard, P.; Calvert, L.D. Pearson's Handbook of Crystallographic Data for Intermetallic Phases; American Society for Metals: Cleveland, OH, USA, 1985.

49. Kraus, W.; Nolze, G. Power Cell-A program for the representation and manipulation of crystal structures and calculation of the resulting X-ray powder patterns. J. Appl. Crystallogr. 1996, 29, 301-303. [CrossRef]

50. Reiher, T.; Lindemann, C.; Jahnke, U.; Deppe, G.; Koch, R. Holistic approach for industrializing AM technology: From part selection to test and verification. Prog. Addit. Manuf. 2017, 2, 43-55. [CrossRef]

51. Boschetto, A.; Bottini, L.; Veniali, F. Roughness modeling of AlSi10Mg parts fabricated by selective laser melting. J. Mater. Proc. Technol. 2017, 241, 154-163. [CrossRef]

52. Frenkel, A.I.; Machavariani, V.S.; Rubshtein, A.; Rosenberg, Y.; Voronel, A.; Stern, E.A. Local structure of disordered Au-Cu and Au-Ag alloys. Phys. Rev. B 2000, 62, 9364. [CrossRef]

53. Younes, O.; Zhu, L.; Rosenberg, Y.; Shacham-Diamand, Y.; Gileadi, E. Electroplating of amorphous thin films of tungsten/nickel alloys. Langmuir 2001, 17, 8270-8275. [CrossRef]

54. Sade, W.; Proença, R.T.; Moura, T.D.D.O.; Branco, J.R.T. Electroless Ni-P coatings: Preparation and evaluation of fracture toughness and scratch hardness. ISRN Mater. Sci. 2011,1-6. [CrossRef]

55. Sudagar, J.; Lian, J.; Sha, W. Electroless nickel, alloy, composite and nano coatings-A critical review. J. Alloy. Compd. 2013, 571, 183-204. [CrossRef]

56. Rajabalizadeh, Z.; Seifzadeh, D. The effect of copper ion on microstructure, plating rate and anticorrosive performance of electroless Ni-P coating on AZ61 magnesium alloy. Prot. Met. Phys. Chem. Surf. 2014, 50, 516-523. [CrossRef]

57. Inberg, A.; Bogush, V.; Croitoru, N.; Dubin, V.; Shacham-Diamand, Y. Novel highly conductive silver-tungsten thin films electroless deposited from benzoate solution for microelectronic applications. J. Electrochem. Soc. 2003, 150, C285-C291. [CrossRef] 
58. Linstrom, P.J.; Mallard, W.G. NIST Chemistry WebBook: NIST Standard Reference Database Number 69; NIST: Gaithersburg, MD, USA, 2003.

59. Luo, Y.R.; Kerr, J.A. Bond Dissociation Energies. In CRC Handbook of Chemistry and Physics; CRC Press: Boca Raton, FL, USA, 2010; p. 89. Available online: https://notendur.hi.is/agust/rannsoknir/papers/2010-91-CRCBDEs-Tables.pdf (accessed on 1 January 2019).

(c)

(C) 2020 by the authors. Licensee MDPI, Basel, Switzerland. This article is an open access article distributed under the terms and conditions of the Creative Commons Attribution (CC BY) license (http://creativecommons.org/licenses/by/4.0/). 